American University Washington College of Law Digital Commons @ American University Washington College of Law

$10-5-2009$

\title{
Reconciliation Financing: An Innovative Approach to Poverty, Inequality, and Social Conflict
}

Daniel D. Bradlow

American University Washington College of Law, bradlow@wcl.american.edu

Follow this and additional works at: http://digitalcommons.wcl.american.edu/fac_works_papers Part of the Law Commons

\section{Recommended Citation}

Bradlow, Daniel David, Reconciliation Financing: An Innovative Approach to Poverty, Inequality, and Social Conflict (October 5, 2009).

This Article is brought to you for free and open access by the Works at Digital Commons @ American University Washington College of Law. It has been accepted for inclusion in Working Papers by an authorized administrator of Digital Commons @ American University Washington College of Law. For more information, please contact fbrown@wcl.american.edu. 


\section{http://www.voxeu.com/index.php?q=node/4051}

\section{Reconciliation financing: An innovative approach to poverty, inequality, and social conflict}

Daniel D. Bradlow

5 October 2009

Historical wrongs have long-lasting consequences. This column says that reconciliation must include a financial component that assists victims of injustice onto sustainable paths to independent lives of dignity and opportunity. It suggests reconciliation bonds.

History teaches us that the present is heavily influenced by the acts and omissions of the past; it warns us that our own decisions and actions can enrich or impoverish the lives of our descendents. Thus, grave historical injustices that do not end with both a clear acknowledgement of the suffering caused and provision of financial support to help the victims fester and constrain our lives and those of our children. For example, the legacies of slavery and colonialism continues to distort personal and communal relations between Africa, the African diaspora, and the rest of the world, and that complicates our efforts to address problems like poverty, inequality, HIV/AIDs, climate change, and racism. Similarly, the legacy of apartheid continues to plague South Africa and threaten its future.

Our efforts to deal with the consequences of these historical wrongs should incorporate the principles of reconciliation financing. Reconciliation financing is an effort to use financial innovation to assist those who suffered from these injustices and their descendents onto sustainable paths to independent lives of dignity and opportunity.

\section{Three principles for reconciliation financing}

Reconciliation financing is based on three principles.

- First, money is an essential element of any genuine reconciliation
Print Email

$\underline{\text { Comment }} \underline{\text { Republish }}$

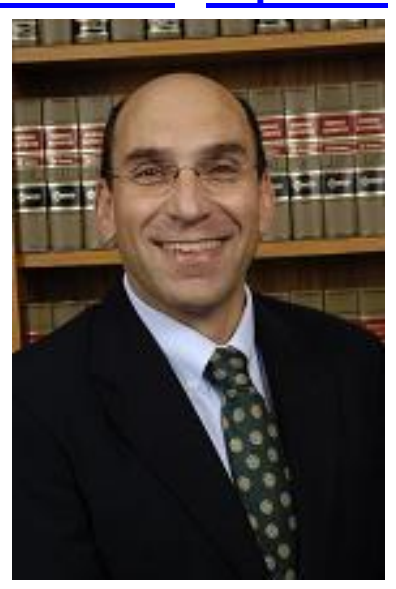

Daniel D. Bradlow

SARCHI Professor of

International

Development Law and

African Economic

Relations at the University of Pretoria, South Africa,

Professor of Law and

Director of the International Legal Studies Program at American University 
effort.

Clearly financing can never fully compensate the victims of injustices like apartheid, slavery, and colonialism for the harm they suffered and its consequences, which often stunt the lives of them and their descendents. However, if appropriately structured, it can help them build lives with more opportunity and dignity for themselves and their children.

The importance of this principle is demonstrated by the most successful example of reconciliation in the past century - the reconciliation of Germany and Jews following the end of World War II. ${ }^{1}$ In this case, the payment of reparations allowed those who suffered under the Nazis to construct better lives for themselves and their children. As their circumstances improved, the sufferers were able to bear the psychic cost that must be paid if they are to move beyond their pain and anger and reconcile with their oppressors.

- Second, "reconciliation financing" must promote projects that create meaningful benefits for those who are poor and lack access to jobs, services, and opportunities.

This means that reconciliation financing should fund projects that are not currently well-supported by commercial sources, governments, or donor agencies. The best candidates for reconciliation financing are small-scale revenue-generating projects like small- and microenterprises and low-income housing. These projects have difficulty raising funds everywhere in the world. They are considered both "too rich" for grant funding because they generate a return that can be used to service a certain level of debt and "too poor" for commercial funding either because of the size of the project or because their rates of return are too low to be attractive to a commercial lender.

- Third, the form in which the reconciliation financing is provided is important.

Grants, which seem to be the most obvious form for such financing, have three weaknesses. 1) They risk exacerbating the existing unequal relations between the recipients and the donors, thereby undermining the reconciliation objectives. 2) By leaving the recipients dependent on the goodwill of the donors, they undercut the goal of promoting independence and self-sufficiency in the recipients. 3) Many potential participants in reconciliation financing are sceptical about the ability of charitable organisations to effectively address the problems of poverty. Consequently, they are unlikely to contribute to grant-funded reconciliation efforts, thereby potentially undermining both their 
reconciliation and development objectives.

\section{Why not equity?}

While equity's risk-sharing characteristic suggests that it could be an attractive option for reconciliation financing, it has two drawbacks. First, there is a risk that the reconciliation investors may use their voting rights to exercise undue control over the investment, thereby undermining the goal of promoting beneficiary self-sufficiency. Second, it could result in situations in which the reconciliation investors appear to be profiting from the hard work of the recipients of the reconciliation financing.

Debt, offered on realistic terms, is the most effective form for reconciliation financing. The fact that debt creates fixed term contractual relationships means that it leaves debtors, after they have fully performed their contractual obligations, with a credit history which should enhance their prospects for accessing future financing. It thereby both contributes to improving the debtors' material situation and promotes their independence.

The extent to which debt promotes development and reconciliation depends, to a significant extent, on its terms. If the borrower perceives them as too harsh, the debt transaction can undermine rather than promote these objectives. On the other hand, if the terms are perceived to be too generous, the transaction will be viewed as a disguised grant which will undermine the goal of promoting independent actors with their own credit histories and access to financing.

\section{Reconciliation bonds}

A retail bond is a particularly effective means for raising reconciliation financing. 2 This "reconciliation bond" can be sold to governments, individuals, organisations, and companies interested in promoting reconciliation and development. In this regard, it is important to recognise that grave social injustices are not caused only by governmental action. They require the active participation of many private actors and the silent acquiescence of many others. Consequently, it is entirely appropriate that both public and private actors contribute to the reconciliation financing effort. In fact, the failure of any of these groups of actors to participate in the financial transaction risks undermining the reconciliation and development effort.

The proceeds of these reconciliation bonds should be invested in smallscale revenue-generating projects that are considered "too rich" for grant 
funding and "too poor" for commercial funding. Even assuming high failure rates, the bond issuer should be able to repay all bondholders and generate some resources to support a permanent "reconciliation financing" mechanism.

\section{Conclusions}

Reconciliation financing offers an innovative way to use market mechanisms, one of the economic strengths of our shared global history, to solve some of its tragic social and economic legacies. Governments have made some tentative moves in this direction. For example, the International Finance Facility for Immunisation converts government pledges of future aid into bonds that have been used to fund vaccinations of children around the world. The Clean Development Mechanism has been used to fund projects that help reduce greenhouse gas emissions. Recently, the French Foreign Minister Bernard Kouchner (2009) and Adair Turner, chairman of the Financial Services Authority (Parker, 2009) both advocated a tax on financial transactions ("a Tobin tax") to help fund development in the poorest developing countries.

These government initiatives do not meet all the requirements of reconciliation financing. Nevertheless, they help demonstrate the potential for financial innovations to deal with historical legacies. Together with private reconciliation financing efforts, like the reconciliation bond, they could become powerful new tools for both financing development and overcoming the tragic legacies of historical injustices like apartheid, slavery, and colonialism. In the process they may also remind bankers that innovations in finance that result in solutions to our most serious social problems offer rewards that are more sustainable and more useful to their descendents than those to be gained from personally profitable but socially useless complex financial instruments.

\section{References}

Bradlow, Daniel (2008), "An Experiment in Creative Financing to Promote South African Reconciliation and Development" in Raj Bardouille, Muna Ndulo, and Margaret Grieco (eds), Africa's Finances: The Contribution of Remittances, Cambridge Scholars Publishing.

David, Roman and Susanne Choi Yuk-ping (2005), "Victims on Transnational Justice: Lessons from the Reparation of Human Rights Abuses in the Czech Republic”, 27 Human Rights Quarterly, 393. 
Kouchner, Bernard (2009), "A Tax on Finance to Help the World's Poor", Financial Times, 16 September.

Parker, George (2009), "FSA Backs Global Tax on Transactions", Financial Times, 27 August.

1. The lesson from the case of German reparations has been confirmed in a study of reparations in the Czech Republic (David \& Yuk-ping, 2005)

2. For a discussion of a Reconciliation and Development Bond for South Africa, see Bradlow (2008).

This article may be reproduced with appropriate attribution. See Copyright (below).

Topics: Development

Tags: $\underline{\text { Reconciliation, reconciliation bonds }}$

WWW.VOXEU.COM 